\title{
'TEACHERS' QUESTIONS IN INDONESIAN EFL CLASSROOM
}

\author{
Ahmadi \\ UniversitasPendidikan Indonesia, \\ ahmadiadi@upi.edu \\ EriKurniawan \\ UniversitasPendidikan Indonesia, \\ eri_kurniawan@upi.edu
}

\section{ABSTRACT}

Despite the abundant advantages of teacher's questions, teachers still do not gain any benefits from them as they face many challenges in posing them. However, teachers who pose questions as a part of the teaching-learning strategy in the class may gain different outputs. A descriptive qualitative study is carried out to find out the types of questions that dominantly posed by a teacher in the intensive listening course at an institute of Islamic studies in Ponorogo. A lecturer and her class took part as participants on the study. Class observations, videotape observation, and interviews were utilized to gather the data. The revised Bloom's taxonomy process verbs, assessment and questioning strategies was employed to analyze the data. The finding shows that the lecturer spent 73.8 percent of her questions on remembering, 17.8 percent on the understanding level, 5.9 percent on analyzing, and 2.9 percent on the evaluating level. It indicates that her questions were dominated by a low level of thinking skill.

Keywords: Questioning, questioning strategy, teacher's question

\section{INTRODUCTION}

Despite the abundant advantages of teacher's questions, teachers still do not gain any benefits from them as they face many challenges in posing them. Some of these obstacles are the distribution of questions, too short a wait time, and the lack of feedback given by the teacher (Yang, 2017). In addition, students' participation in responding to the teacher's questions 
becomes another challenge for teachers (Chin, 2006). Related to the distribution questions, some teachers tend to ask only clever and active students and avoid the reluctant students. It might be caused by a lack of patience for some teachers (Yang, 2017). The impatience also leads to the short of wait time. Sometimes the teachers ask more questions before the students answering the previous one. The result, the students do not have enough time to give a proper response to the questions. The next problem is the lack of feedback which is provided by the teachers. Some teachers sometimes do not give evaluation and judgment over the students' response. If they give an evaluation, often in a short expression, such as "good", "right", or "marvelous". It is expected that the teachers will be more benefited from their questions if they are aware of the challenges.

Teachers who pose questions as a teaching-learning strategy in the class may gain different output. Some of them are able to motivate their students to advance their learning, while others might demotivate students to learn. It is the nature for teachers to ask a lot of questions to students. Most teachers begin interaction in the class by posing a question (Yanfen \& Yuqin, 2010). In addition, Almeida (2012) asserts that the teacher's questioning dominates the classroom discourse. In one hand, the teacher's questions foiled to develop and arouse students' learning (Noor, Aman, \&Mustaffa, 2012).

On the other hand, the teacher's questions are able to support the teachers in improving the teaching-learning process in their classrooms. They are believed to be able to help students to be more focus on lessons, train students' discipline, increase participation in learning, and keep learning to go on the right track (Fakeye, 2007). In addition, the teacher's question can also generate interactions between students both within a group and individuals (Rahman, 2013). Hence, further exploration of the topic needs to be carried 
out.

The present study investigated the teachers' questions in Indonesian EFL classrooms. It explored the type of questions posed by teachers in an intensive listening course. The study is expected to increase the repertoire of the researches and knowledge in this field because many studies have studied the teacher's questions on various language learning areas, such as in writing, reading, and English based instruction (Davoudi \& Sadeghi, 2015).

\section{LITERATURE REVIEW}

One form of classification of questions is the classification based on the cognitive level involved known as Bloom's taxonomy, first proposed by Bloom, which was later revised by Krathwohl (2002). This classification involves two cognitive levels of low and high cognitive. Included in the low order cognitive category are questions that are classified as remembering (knowledge), understanding (comprehension), and applying (application). Analyzing (analysis), evaluating (evaluating) and creating (synthesis) fall into the high order cognitive question category. The terms in parentheses are terms used by Bloom in their categorization. Each level of this question requires different cognitive actions. Remembering questions require listing, naming, identifying, showing, defining, recognizing, recalling, and stating actions. While understanding questions expect students to be able to summarize, explain, interpret, describe, compare, restate, distinguish, visualize, and paraphrase. Solving, illustrating, calculating, using, interpreting, relating, manipulating, applying, classifying, modifying, and practicing are cognitive actions that are required by applying question taxonomy level.

Analysis questions require students to be able to dismantle a material and find out its constituent components. They are also expected to be able to connect the constituent components of the material. Analyzing questions 
also allow students to organize and arrange the elements contained in a structure, distinguish related elements and those which are not related to the main structure, or reconstruct an arrangement that is independent of bias following the values that the arrangement has. In addition, the evaluating questions encourage students to assess a concept based on standard that are previously set. Evaluating questions also enables students to judge a work, determine the feasibility of a product and its manufacturing process, or it may also determine the accuracy and consistency of a theory (Tofade et al, 2013). On the other hand, creating the highest category of cognitive questions requires students to be able to offer alternative solutions to a problem by developing a hypothesis to complete a task and produce a new concept.

\section{RESEARCH METHOD}

\section{Design of study}

A qualitative approach enables a researcher to investigate a specific phenomenon and people's history (Silverman, 2005), besides it also seeks insight into meaning that people present to the world (Creswell, 2009). Since the study describes and explains certain phenomena, it requires a descriptive analysis which characterizes the world (Loeb, Dynarski, McFarland, et al, 2017). The analysis classifies, describes and explains the questions that are posed by an Intensive English listening teacher. Therefore, a descriptive qualitative study design is appropriate for the study.

\section{Participant of study}

The participants of the study are selected based on purposive sampling. A lecturer in an institute of Islamic studies who teach English intensive listening courses and the students in her class were the participants 
in this study. She was chosen because she teaches on a reputable major at a university in the town, and she possesses good teaching and interpersonal skills.

\section{Data Collection and Analysis}

The data of this study were collected through class observation, videotape observation, and interview. They were carried out to seek the interaction between the teacher and the students concerning how they pose and respond to questions. The data obtained from videotaping and classroom observation, the questions that are aroused will be transcribed. The question transcription then will be coded and grouped based on the revised Bloom taxonomy framework (Krathwohl \& Anderson, 2001).

\section{FINDINGS AND DISCUSSION}

The teacher posed a lot of questions in her class. During the three times of observation, she posted 337 questions to her students in the classroom. The questions covered73.8 percent of remembering level, 17.8 percent on understanding level, 5.9 percent on analyzing and 2.9 percent on the evaluating level. Since the opening until the closing of the class, she asked the students many things. She opened the class with the greeting and asked the students about their condition. Then she checked the students' listening reception by posing questions. Sometimes, she made a joke by delivering questions to the students. She also gave the students advice about listening learning and life lesson, which was initiated by questions. The teacher also asked the class to evaluate their learning progress. At the end of the meeting, she posed questions to make sure that they didn't miss anything related to the learning materials that should be covered for that day. These phenomena are similar to which the description that Yanfen and Yuqin, (2010) provides 
that most teachers open their classrooms by posing questions. Furthermore, they also support Almeida's (2012) assertion that the teacher's questioning dominates the classroom discourse.

The teacher posed any kind of question. She varied her questions based on the situation that they encountered during the teaching learning process. In the beginning of the class, she employed remembering questions to encourage the students to recall their experiences related to the topic that was being discussed on the meeting. The questions served as a bridge that connects the students' experiences to the new learning materials and also as an attempt by the teacher to get the students to engage in the learning process (Taylor \& Parsons, 2011). In addition, almost after each listening section, she posed remembering and understanding questions to check the students' reception over the listening materials which they had heard. Sometimes, she asked the students whether they had encountered the same situation on the recording by asking the analyzing questions. She asked the students to analyze the situation on the recording and then to compare to their experiences. It was expected that the students would catch the learning goals easier as they could relate the learning to their experiences. As the class came to an end in the day of the session, she asked the students to look back on the teaching-learning process that day and to evaluate whether they have acquired new knowledge and skills by proposing evaluating questions.

Each learning condition has its own characteristics and requires different management. As circumstances change, adjustments are encouraged to be taken into action. In a classroom, learning activities are designed in a structured way to make students to gain maximum learning result and the best learning experiences (Richards, 2011). They begin with an introduction of a topic, followed by a series of main learning and closed by an evaluation. 
Each stage requires a teacher to perform different actions. They also need different questions to start and end each stage. For example, a teacher may ask light yet interesting questions to open a class. Then, in the middle of teaching learning process, she may ask questions related to learning topic to maintain the students to keep focus on the learning. As a closing stage of the today learning, a teacher may ask students to conclude the learning, which parts are still missing, what they have learnt and wrap up of the session.

In posing a question, the teacher had different purposes. At the beginning of the session in a class, she attempted to ask an interesting question to gain students' attention and to prepare them to enter the learning material of the day. Beside as an attention gather, the question also served as an effort to make the students felt comfortable during the rest of the class. Also, questions were intended to check the students' understanding related the topic that was being discussed. Afterwards, the teacher asked questions to form a harmonious communication with and among the students. It is a good way to make a relationship (Heritage, 2002). Furthermore, the teacher asked the students to raise their awareness on the learning topic and also their confidence. The questions usually were about on the low order of thinking level. Another goal that the teacher wanted to achieve by posing questions was that she wanted to prepare the students to face the next challenge in the following level as they are required to join the next level of listening course in the following semester.

Teacher's questions serve many purposes (Yang, 2017). By proposing the right questions, a teacher can gain different goals. Students become more confidence in a classroom when they can answer their teacher questions correctly (Fakeye, 2007). Teacher's questions also can be a useful way to start and maintain conversation and interaction in the classrooms (Al-Zahrani \& 
Al-Bargi, 2017; Farahian \& Rezaee, 2012). The interaction is expected in a smooth relaxing during teaching learning process. In maintaining this, a teacher can propose questions, they might be in form of funny jokes or it may take form as a riddle. Another function of the teachers' questions is that they can promote feedbacks. Teachers tend to ask questions before giving feedbacks and suggestions on the students' learning problems(Al-Zahrani \& Al-Bargi, 2017). The teachers are there to provide students help when they need assistance. They try to ease the students' burdens by giving an assistance. Since the teacher had been in their position, she might be has a solution to their problems.

In proposing the questions, the teacher had several reasons. The first, they had to cover a lot of materials which encouraged them to discuss various topics. The materials are compulsory learning which are stated by the institution plus additional materials that are selected for them to make the class warmer and enjoyable to learn in. The next reason was that to make the teaching learning process became fun and the students were happy for being in the classroom. She believes in the fact that when students are happy and comfortable in the classroom, they gain more knowledge and skills in a such comfortable way, and the most important aspect is that they are willingly to take a part on the learning process as they grow up in each session. The last reason for posing questions was the teacher's awareness that the students would face greater challenges in the future. So, she shared her concern to her students by providing them various problematic situation, both in low and high level of thinking skills.

Students discover more on learning when they are in a relax situation. The situation can be created when they are happy and enjoy the process (Lucardie, 2014). Posing questions can help a teacher to design such 
situation. The teacher needs to proposed questions which are on the level of students' mastery on certain topic. Students might be nervous when about to be asked, but when they realize that the questions are not that difficult, they will get ease and get prepared for the next questions, which in turn they are prepared for the whole learning process.

\section{CONCLUSION}

The goals of teaching learning can be achieved by posing the right questions. Teachers may propose various types of questions depending on the circumstances that require them. The questioning is an attempt for the teachers to ensure their students to gain the maximum learning results and learning experiences.

\section{Acknowledgement}

The researcher would like to express deep gratitude for Indonesia Endowment Fund for Education (LPDP) without which this research would not have been accomplished.

\section{REFERENCES}

Almeida, P.A. (2012). Can I ask a question? The importance of classroom questioning. Procedia-Social and Behavioral Sciences, 31(2012), 634-638.

Al-Zahrani, M.Y. \& Al-Bargi, A. (2017). The impact of teacher questioning on creating interaction in EFL: A discourse analysis. English Language Teaching 10 (6), 135-150.

Chin,C.(2006).Classroom interaction in science: Teacher questioning and feedback to students ${ }^{\mathrm{ee}}$ responses. International Journal of Science Education, 28 (11), 1315-1346. 
Creswell, J. W. (2009). Research design: Qualitative, quantitative, and mixed method approaches $\left(2^{\text {nd }}\right.$ ed). Thousand Oaks, CA: Sage Publications.

Davoudi, M., \& Sadeghi, N.A. (2015). A systematic review of research on questioning as a high-level cognitive strategy. English Language Teaching, 8(10), 76-90.

Fakeye, D. (2007). Teachers' questioning behavior and ESL classroom interaction pattern. Humanities and Social Sciences Journal, 2(2), 127-131.

Farahian, M., \& Rezaee, M. (2012). A case study of an EFL teacher's type of question: An investigation into classroom interaction. Procedia Social and Behavioral Science, 47(2012), 161-167.

Heritage, J. (2002). 'The Limits of Questioning: Negative interrogatives and Hostile question content', Journal of Pragmatics, 34(2002), 142746.

Krathwohl, D. R. (2002). A revision of Bloom's Taxonomy: An overview. Theory into Practice, 41 (4), 212-218.

Loeb, S., Dynarski, S., McFarland, D., Morris, P., Reardon, S., \& Reber, S., (2017). Descriptive analysis in education: A guide for researchers. (NCEE 2017-4023). Washington, DC: US Department of Education, Institute of Education Sciences, National Center of Education Evolution and Regional Assistance.

Lucardie, D., (2014). The impact of fun and enjoyment on adult's learning. Procedia-Social and Behavioral Sciences, 142(2014), 439-446.

Noor, N. M., Aman, I., \& Mustaffa, R. (2012). Teacher's questioning approaches in the Malaysian ESL classroom. The International Journal of Learning, 18(7), 313-326.

Rahman, Kh. A. (2013). Current perspective on teacherquestioning in English language classrooms. Journal of Science and Technology, 5(2), 3-12. 
Richards, J., (2011).Creating creative language lessons. New York: Cambridge University Press.

Silverman, D. (2005). Doing qualitative research: A practical handbook. Thousand Oaks, CA: Sage Publications.

Taylor, L. \& Parsons, J. (2011). Improving student engagement. Current Issues in Education, 14(1). Retrieved from http:/ / cie.asu.edu/

Tofade, T., Elsner, J., \& Haines, S.T., (2013). Best practice strategies for effective use of questions as a teaching tool. American Journal of Pharmaceutical Education, 77(7), 1-9.

Yanfen, L. \& Yuqin, Z. (2010). A study of teacher talk in interactions in English classes. Chinese Journal of Applied Linguistics, 33 (2), 76-86.

Yang, H. (2017). A research on the effective questioning strategies in class. Science Journal of Education, 5(4), 158-163. 